\title{
The Library of the Future: Musings on the Politics of Meaning by Scott Cowdell
}

\author{
Associate Professor Scott Cowdell is a Research Fellow \\ in the Charles Sturt University Public and Contextual \\ Theology Strategic Research Centre, based at St Mark's \\ National Theological Centre, Canberra, and Canon \\ Theologian of the Diocese of Canberra and Goulburn.
}

I was particularly gratified when asked to address this gathering of Australian and New Zealand theological librarians on The Library of the Future because, in truth, I am fast becoming an honorary theological librarian myself. The St Mark's Library team will testify to this: not only did I spend the first eight months of my present research fellowship at a desk in their library, due to space constraints when a new office building was late opening, but in the rare books room itself, where I was preserved among the other treasures at a uniform temperature of sixteen degrees Celsius. This ordeal helped forge a bond with the library staff (one that survives my regular approaches to them cap in hand having failed to order interlibrary loans online and download articles from journals now held electronically), but the extreme cold also proved very conducive to writing-so much so that I have opted to spend study leave next year in snowbound Collegeville, Minnesota, with an office in the Alcuin Library at St John's University, all furthering my claim to honorary theological librarianship!

As I begin to address this theme The Library of the Future, let me be clear where my own heart lies. I have always cherished theological libraries as places of peace and quiet communion. I think of the Roscoe Library at St Francis' Theological College, Brisbane, where I was trained, as a cherished haven of exploration and reflection, especially on long Saturday afternoons working alone there, or late at night by lamplight as the college slept but the books were wide awake. Of course the door was never locked. I remember fondly a nonborrowing library at the old Banyo Seminary, where every student had their own desk, also the heavy, nurturing quiet of a seldomvisited library tucked away at the Mercy Sisters' Generalate in Brisbane, where our annual college retreat took place-it was there in blissful and total solitude that I first discovered the boundary between reading and praying giving way. I have valued my time in really energetic theological libraries, too- the Joint Theological 


\section{"And in this, of}

course, the library

is no different from

the educational

enterprise

as a whole,

and our other

social, cultural

and religious

institutions, all of

which are under

pressure to reinvent

themselves in our

deregulated, post-

modern West."
Library in Melbourne, for instance, and Moore College Library in Sydney, where everything I wanted seemed to be available. Yet the world of theological libraries is changing. Which of us nowadays would be content without our electronic access to theological journals, to searchable library catalogues online, and to the many eresources now available both to the student and to the theological scholar? And yet how wonderful the opportunity that theological libraries still provide, especially in today's hectic world of theological education, just to be able to sit, to explore, and perhaps to daydream a little in the tangible company of the saints.

If I am revealing a lingering bias in these remarks for browsing and savouring and for quiet library corners, it is because I sense a tension in this whole matter, not least in myself, between an older agenda for theological libraries and the brave new world we are entering. This tension is perhaps reflected in the striking brochure accompanying your conference, in which a program totally committed to worthy new technologies and digital resource management is packaged with words and symbols of discovery from the Victorian age- that great era of library, of canon and of resolute conviction-including images of an explorer's compass, and of Charles Darwin's travelling microscope. In what follows I want to try and tease out that tension, engaging first in a little futurology and then in some hermeneutics of suspicion about the underlying mindset of our digital age. Because there is a real ambivalence about the cusp on which we find ourselves, poised between the weight of our past, reflected not least in the tonnage of books we store in our libraries, and a new digital future offering fewer encumbrances no doubt but at the risk of losing muchneeded cultural ballast. And in this, of course, the library is no different from the educational enterprise as a whole, and our other social, cultural and religious institutions, all of which are under pressure to reinvent themselves in our deregulated, postmodern West. Then, I will leave you with some theological thoughts about what it is that a theological library in particular might stand for among Christians. These are things we will need to safeguard as we leave behind the age of paper books in numerous local collections for tomorrow's market driven promise of greater efficiency, access and choice.

I

I first realized that change was afoot in the world of libraries in the early nineties when I was a parish priest on the northside of Brisbane, back before the digital revolution took off. The local Chermside Public Library put out a big, colourful sign about school holiday activities for local children and young mothers, with craft, games, plays and so forth - all great fun, but then I noticed that there was no mention at all about books or reading. Probably wise I wryly concluded, because that might have stopped potential 'customers' from coming to the library. Here we see library re- 
"Hence new power

elites arise to fill

the vacuum left

by nation states,

Churches and

culture's guiding

narratives - all

of which are still

there, though they

are increasingly

transformed by

the commercial

imagination into

mere brands and

lifestyle choices." imagined as community centre. As for books themselves, I was struck at that time by a scene in the 1990 science fiction film Frankenstein Unbound, in which the scientisthero played by John Hurt, in the year 2031, needed to get hold of Mary Shelley's novel Frankenstein when he was on the road-so he called up the book on his car's computer with the whole text emerging from a dashboard printer within seconds. Now, not twenty years on, I can do the same thing at home with journal articles through the university's online library catalogue, also check many scholarly references on Google Books, look inside potential purchases on Amazon.com, and have the option of downloading books to an easy-to-hold portable device offering a creamy, matt reading surface like paper. I can imagine that in my quiet scholarly retirement, if not before, I will not need to actually visit a theological library at all, but will have access to any and every published book online, not to mention the ability to download whatever movie or TV rerun I could possibly want to watch that evening. My St Mark's colleague Christene Babington informs me that a recent library magazine carries pictures of a new Korean library which is all terminals linked to managed databases, with no books at all. Some will be thrilled by this development, but others will be at least faintly disquieted.

Some more recent cinematic visions of the future pick up on such disquiet, seeking to offer reassurance. So Captain Kirk in the Star Trek movies reads old books in his cabin through halfmoon glasses, and Captain Sulu is brought tea in a standard Federationissue china cup and saucer on the bridge of his starship, while Captain Picard orders his from a hightech gizmo with the command 'tea; earl grey; hot'. In a striking double take, the makers of a futuristic Tom Cruise thriller Minority Report began their 2002 film with a reassuringly traditional vista of a leafy Victorian residential streetscape in Georgetown, featuring two mounted policemen on patrol, then added the caption 'Washington DC, 2054'. But all of this is surely nostalgia driven. If we give free reign to our fear of change, it leads to cinematic dystopias such as the Terminator films. Hence today's cult of nostalgia, as a very bankable postmodern industry aimed at dispelling anxiety over a future out of control.

Postmodernity and the global market, both powerfully symbolized by that deregulated, postdemocratic kingdom of everyman called the Internet, is at the same time a potentially restricting world, with corporate monopolies and powerful voices gaining purchase on our imaginations now that traditional prohibitions and hierarchies of meaning and verification are draining away. It is a world of Microsoft, Yahoo, Google and Amazon.com, of marketing, advertising and endless sales. Hence new power elites arise to fill the vacuum left by nation states, Churches and culture's guiding narratives - all of which are still there, though they are increasingly transformed by the commercial imagination into mere brands and lifestyle choices. The allegedly hyper-democratic world of the Internet is in fact a 


\section{"I can imagine}

a digital future

where all human

literature becomes

a vast database

essentially under

commercial control,

which will mean

an end to libraries

since we can all

access everything

online more

cheaply." great reinforcer of predictable commercial priorities. Increasingly, we Westerners belong only to the commodity form, and everything from morality to religion, as well as personal identity, is now up for sale. So the more digital we go, the more likely that corporate money and power will get hold of intellectual property, withholding or dispensing it according to market considerations. I can imagine a digital future where all human literature becomes a vast database essentially under commercial control, which will mean an end to libraries since we can all access everything online more cheaply.

And what about theological libraries? For many Churches today, facing their own dwindling market share and seeking renewal with the help of management thinking, an increasingly pragmatic bottom line culture and the business values accompanying it mean that Christianity is no longer about an idea or a vision with roots in something beyond the market, which will still galvanise and transform us if given a chance. Instead, institutional survivalism is the order of the day, with Church leaders grabbing at whatever seems to work. Theological education is thus reduced regularly either to indoctrination or else to practical upskilling. In the latter case its intellectual component serves essentially a finishing school function, meant to turn out plausible graduates who will not embarrass us by nursing theological convictions or spiritual enthusiasms. In both cases, serving an agenda either of indoctrination or of finishing school, a theological library service available online would certainly suffice, rather than maintaining a fusty old paper library, just as Churches can now outsource theological education to online distance education providers or nondenominational Bible colleges, all of which can deliver the limited range of desired product. So, if the digital future belongs to the managerial, corporate imagination, why would we think that the Churches will not more fully embrace that culture and dispense with their theological libraries-especially in Australia, where the Churches have demonstrated little historical commitment to nurturing theological culture?

In Ray Bradbury's moving novel Fahrenheit 451, which is the temperature at which books will burn, we see one particular view of the library's future. Firemen like Guy Montag have been redeployed for the burning of books, so their totalitarian masters can keep a lid on the public picking up disturbing ideas. Perhaps in a less extreme future librarians will be those who scan books, compile databases and disseminate useful links, or perhaps run a kind of help desk for readers, unless of course just clicking the help button will suffice. But there's something about books, as Guy Montag discovers when a copy of David Copperfield which he rescues from an inferno and reads painstakingly in secret gives him access to a whole underground of people who are not in the system's power, at least imaginatively, including dedicated individuals who have memorised whole books to keep these texts alive, since the paper volumes are in danger of disappearing forever. This suggests a potentially subversive vocation 


\section{"This suggests}

\section{a potentially}

subversive vocation

for the theological

library, and

the theological

librarian, not

to mention the

theologian,

as stubborn

champions of

a currently

undervalued

resource." for the theological library, and the theological librarian, not to mention the theologian, as stubborn champions of a currently undervalued resource. You may remember a surreal lateeighties BBC comedy called A Very Peculiar Practice, set in the eponymous Lowlands University, about the encroachment of vulgar business culture on academia. At the start of each episode, early in the morning as the garbage trucks roll around the modernist campus buildings to empty the skips, nuns in traditional habits are seen rushing from the scene carrying away classical statues and other cultural artefacts before they end up in the rubbish compactor. There may well be something like this at stake as we assay the future of theological libraries.

Mind you, digitizing the world's literature may also help to protect it. You can imagine a future civilization, before it perished from harsh climate change or an unavoidable asteroid impact, gathering up all that data representing the sum total of human writing and beaming it into the heavens, as one huge compendium of all that we were, hoping that it may ultimately find a reader, out there among the unseeing stars-like the last forest from earth embarked with its robot gardener on that giant transparent spaceship by a dying Bruce Dern in the 1972 environmentallythemed science fiction classic Silent Running, because all the rest of Earth's forests had been destroyed, while Joan Baez sang in voiceover 'tell them it's not too late'. So the digital future might just be desirable after all-not only might it enhance the dissemination of all that we love in the world of books, but it might also serve as a better chance of preserving this legacy. How this turns out may depend on how we think and act at this hinge moment when decisions about the future of libraries, theology and theological libraries are being made. Now let me finish with some specifically theological considerations about what I think is at stake here.

\section{II}

There is something stubborn and even obsessive about our God.The Bible testifies to God's patient engagement with a particular people, and the places where they live, to love them, heal them, challenge them, and to set them right-with God, with themselves, with one another and with the world. This is enormously earthy, creationinhabiting and historical, this saga of Israel and the Church-this 'human story of God', as Edward Schillebeeckx beautifully puts it. At the heart of this story, as the Catholic imagination receives it, is the incarnation, which is both the celebration of God's radical terrestriality and its crowning achievement. Jesus is the word made flesh, the word made human, that is, and historical, and specific, and in our hands. From this central imaginative fruit of Israel's earthy faith comes a redemption which is not an escape from the world, but the beginning of our world's new creation-in Jesus' life and death, in the teeth of human self-destructive folly, to his raising by God as the vindication of God's total commitment to human transformation 
"Hence the sheer

weighty, lumpy

givenness of

theological books,

and of theological

libraries built up

over long periods,

and of local

collections that help

tell God's story in

that special place." in the cross. And from this universal breakthrough comes the outpouring of God's spirit in the world, making this transformation accessible and urgent in every time and place. Hence the Church and its sacraments, continuing under the veil of bread and wine, and of fallible human communities, and of flawed but persistent disciples, the investment of God in the actual life we live- - a life of distinct places, slivers of history, particular relationships and concrete institutional circumstances. Here is the incarnational, redemptive compass of the biblical imagination.

Consequently, the Church and its saints are to be regarded as essential living signs of God's prophetic spirit at work in the world, with the communion of saints included among our official beliefs in the creed. I understand the Lutheran concern about claiming sanctity as something achieved, and the broader Protestant concern to keep attention on Christ and not give way to what Paul Tillich called 'the medieval bureaucracy of salvation'. But we do not want to find ourselves falling under Jesus' condemnation as those who build the tombs of the prophets (Matthew 23: 29-30), putting the often confronting witness and testimony of the saints out of our sight. Because their testimony is Jesus' own testimony. As Gerard Manley Hopkins unforgettably put it, in his poem As Kingfishers Catch Fire,

Christ plays in ten thousand places

Lovely in limbs and lovely in eyes not his

To the Father through the features of men's faces.

I am reminded, too, of the Epistle to the Hebrews, imagining our life and mission as Christian disciples as a footrace, before a stadium of cheering onlookers eager for our success-a great cloud of witnesses (Hebrews 12:1). This is the communion of saints.

My theological point, then, is twofold. First, there is an irrevocable localness, 'historicalness', community embeddedness, and particularity about the Church's universal God. Today's global, postmodern culture-which moves fast, spends big, and knows no place as home; which treats local places either as marketable destinations or else as ghettos for warehousing the losers in our global economy-is cut off from the vital logic of Christian spirituality. Local Churches, communities, buildings with addresses and histories in each place, tell the story of God's commitment to the only life that is really human. Hence the sheer weighty, lumpy givenness of theological books, and of theological libraries built up over long periods, and of local collections that help tell God's story in that special place. All this is deeply consistent with the new spiritual politics that is making Christians into great friends of the Earth, of its creatures, of the suffering people in every place, and of local cultures and traditions everywhere as vehicles fit for embracing God's presence. In other words there is something theological about having theological libraries-their logic is in keeping with the logic of God's proven way of investing in our world: material, human, historical, communal. This is why theological libraries, like 


\section{"A lot of how this}

pans out may well

depend on us, who

seem to have been

called by God to

love, to develop,

and to care for

theological libraries

at a time when

their future is at

stake, for good or

ill."
Cathedrals and theological colleges, Church hospitals and schools, parishes and geographic dioceses, pastors and bishops, are important markers of what it is to see the world in a Christian way. We need all of them, or we risk having our agenda set by some other, possibly less human priority - like the culture of managerialism, for instance, which theologian Richard Roberts has called a 'posthuman' project. This is a major current example of what the Bible calls idolatry.

To clarify my second theological point: theological libraries are concrete symbols of our belief in the communion of saints, and their continued presence is a concrete statement of our unwillingness to forget, to build the tombs of the prophets and to follow commerciallydriven postmodern culture in seeking our identity elsewhere. The theological library is a sign of that fellowship that defines who we are, just as the many spiritual and theological struggles it preserves on its shelves remind us of the canonical vision at the heart of who we are, distilled from practice into the sharp draught of theological and spiritual conviction. As we sit among these books, taking a quiet moment in the running of our race, the communion of saints looks on from the shelves and we find ourselves running our race with their support.

So, to conclude. If the theological library of the future, though it be electronic, can continue to honour these commitments-if all those situated, storied communities celebrating God's incarnate, sacramental, ecclesial investment in the world can ensure that the spiritual resources of Christianity's past, along with its present creative edge, remain accessible at the centre of their life-then we may not need paper books in myriad local collections. Though I believe the onus of proof lies with those who would do away with them. And if the saints are to lose their corporeal presence on the shelves of theological libraries (which are the major reliquaries remaining to us), then we will need to ensure that their voices remain alive among us in digital text-or else, despite whatever efficiencies we achieve, we risk ceasing to be the Church of saints and martyrs. A lot of how this pans out may well depend on us, who seem to have been called by God to love, to develop, and to care for theological libraries at a time when their future is at stake, for good or ill.

\section{Books by Scott Cowdell}

1. Abiding Faith: Christianity Beyond Certainty, Anxiety, and Violence (Eugene, OR.: Cascade, 2009)

2. The Ten Commandments and Ethics Today (Melbourne: Acorn, 2008)

3. God's Next Big Thing: Discovering the Future Church (Melbourne: John Garratt, 2004)

4. A God For This World (London \& New York: Continuum, 2000)

5. Is Jesus Unique? A Study of Recent Christology (Theological Inquiries Series; Mahwah, NJ.: Paulist, 1996)

6. Atheist Priest? Don Cupitt and Christianity (London: SCM, 1988) 